Pobrane z czasopisma Studia Iuridica Lublinensia http://studiaiuridica.umes.pl Data: 26/04/2023 15:30:08

Articles Studia luridica Lublinensia vol. XXX, 5, 2021 DOI: $10.17951 /$ sil.2021.30.5.13-28

\title{
Mohammad Ali
}

UIN Sunan Ampel Surabaya, Indonesia

ORCID: 0000-0003-2237-6845

alialwahid07@gmail.com

\section{Siti Sariroh}

KH Achmad Siddiq State Islamic University, Jember, Indonesia ORCID: 0000-0002-3398-6561 iera.sariroh@gmail.com

\section{Rumawi}

KH Achmad Siddiq State Islamic University, Jember, Indonesia ORCID: 0000-0003-3446-2222 rumawirumawi@gmail.com

\section{Social Construction of Widow's Marital Rights without Finishing Waiting Period (Idah) in Indonesia}

Społeczna interpretacja praw małżeńskich wdowy bez zachowania okresu oczekiwania na zawarcie ponownego małżeństwa według prawa islamskiego (okres iddah) w Indonezji

CORRESPONDENCEADDRESS: Mohammad Ali, Doctoral Candidate at Brawijaya University, Lecturer at Sharia and Law Faculty of State Islamic University of Sunan Ampel, street Ahmad Yani Number 117, Jemur Wonosari, Wonocolo District, Surabaya, East Java 60237, Indonesia; Siti Sariroh, Lecturer at State Islamic University of Kiai Haji Ahmad Siddiq, street. 1. Mataram no. 1, Karang Miuwo, Mangli, Kaliwates District, Jember Regency, East Java 68136, Indonesia; Rumawi, Senior Lecturer at Sharia Faculty of State Islamic University of Kiai Haji Ahmad Siddiq, street. 1. Mataram no. 1, Karang Miuwo, Mangli, Kaliwates District, Jember Regency, East Java 68136, Indonesia. 


\section{ABSTRACT}

Marriage without finishing idah is considered a legal action and allowed for unregistered divorced women. It was implemented by H.S. who divorced her husband T.B. after he abandoned her and went to Malaysia for one year and three months. Madurese, especially Landak village are religious communities. However, this social reality has denied that Landak people are religious communities. This article deals with two research problems: 1) How is the social construction of married women without finishing idah? 2) What are the opinions of the social construction of religious figures and society about marriage without finishing idah in Landak village, Bangkalan Regency, Madura, Indonesia? The result of this research reveals that the social construction of married women without finishing idah: 1) the social construction of married women without the idah indicates an idealistic motivation and that there is a practical and a business motive; 2) according to the construction of religious figures and society, the first - idealistic - motive is to prevent the greater damage, the second - practical - is the family welfare, and the third are "humanism" and" society" aspects as interest motive, and fulfilling the subject interest is as practical motive.

Keywords: marriage; idah; divorce; social construction

\section{INTRODUCTION}

Marriage without finishing $i d a h^{1}$ for unregistered divorced women in Landak village, Tanah Merah District, Bangkalan Regency, Madura, is considered as legal act and allowed for unregistered divorced women. It was implemented by H.S., who divorced her husband after he abandoned her and went to Malaysia for one year and three months. According to H.S., for a year and three months considered as $i d a h$, and to clean the uterus (no fetus), because she never got sexual intercourse and economic needs of her family. ${ }^{2}$

Initially, marriage without idah in Landak society is a forbidden action. However, the community interactions, both individually and in groups, lead to social changes, such as the practice of marriage without finishing idah. The marriage practice is gradually considered to be allowed, especially by unregistered divorced women. In addition, due to being abandoned by her husband, never having sexual intercourse, urgent economic needs and also they got legitimacy from religious leaders that there is no prohibiting, giving religious understanding and social sanction against the marriage practice.

Islam has explained clearly about idah both in holy Qur'an and Hadith, that "divorced women shall wait concerning themselves for three monthly periods. Nor is it lawful for them to hide what Allah Hath created in their wombs" (Al-Baqarah (2): 228).

1 Kamus Besar Bahasa Indonesia, Idah, https://kbbi.web.id/idah-2 [access: 10.11.2021]. According to this definition, it is waiting periode (forbidden to get married) for divorced women.

2 H.S., Interview, Landak, 13 August 2016. 
The verses explained that divorced women shall wait concerning themselves for three monthly periods to clean their wombs. As Rasulullah SAW has been said in a Hadith: "[...] told to us Ahmad bin Muhammad bin Tsabit Al Marwazi, told to me Ali bin Husain from his father from Yazid An Nahwi from Ikrimah from Ibnu Abbas, he read the verse: 'Divorced women shall wait concerning themselves for three monthly periods', and: 'And those who no longer expect menstruation among your women - if you doubt, then their period is three months'. Then part of the verse deleted, he read the verse: 'then divorce them before you have touched them, you may not require them to observe a waiting period that you might reckon against them' (HR Abu Daud No. 1942)". 3

The authority in determining Islamic law (tasyri') is God and His messenger. There was al-Quran which is clear and certain (qath' $i$ ) and there was also general verse (dhanni). Then the general verses of al-Quran are needed to be interpreted ijtihad in order to get an explanation about the verse and to get a concrete answer to the conditions and socio-cultural development of an increasingly complex society. Human interpretation of this verse of the Qur'an is called fiqh which is impermanent. This matter still needs to be held a discourse that aims to get clarity on the context that is in accordance with the intent contained in the general verse of al-Quran, besides that there was Hadith of the prophet (as-sunnah) as an explanation of the text of the Qur'an. ${ }^{4}$

In this matter, related to the verse of the Qur'an about idah for divorced women who will get married again is still needs to be interpreted clearly ijtihad. It aims to get a clear understanding of what is meant by "waiting period" for divorced women to have their next marriage. Then the result of the ijtihad in Islamic law is known as figh (collection of ijtihad of the scholars). Through this interpretation of the text, the context method gave legal options for divorced women to get their second marriage in accordance with the condition of a long time separate with husband before the divorce. Therefore, the law of $i d a h$ in society life is problematic.

Idah (waiting period) for divorced women in Islamic fiqh has many interpretations. It is divided into several conditions. According to Sayyid Sabiq, idah for women who gets menstruation is three times of the menstruation; idah for menopause women is three months; idah for pregnant woman is until she gives birth; and $i d a h$ for a woman whose husband died is four months and ten days if the woman is not pregnant. ${ }^{5}$ Most Islamic scholars stated that the obligation of idah is from ta'abbudiy concept (servitude to Allah). Therefore, the law of $i d a h$ does not have illat (reason), unless it is just a goal or wisdom. However, for some kinds of idah

Abi ‘Abdillah Bin Muhammad Bin Yazid Ibn Majah, Sunan Ibn Majah, Riyadh 1998, p. 219.

4 M. Yusuf, UIN Ar-Raniry Banda Aceh, Build Figh Contemporer Concept, "Journal of Syarah" 2020, vol. 9(2), p. 199.

5 S. Sabiq, Fiqh as Sunnah, Beirut 1988, pp. 277-278. 
some Islamic scholars have a different understanding, i.e. according to them idah refers to divorced women and also to those who give remission with certain reason and dan condition of the women.

Indonesia is a country with a predominantly Muslim population, which also regulates how the idah should be carried out, as contained in Article 8 of Act no. I of 1974 about marriage that "Having a relationship which by his religion or other applicable regulations is prohibited to marry". ${ }^{6}$ And also explains in Compilation of Islamic Law Article 40 (b): "A woman who is still in the idah period with another man is forbidden to marry".

Buya Hamka describes Madura as an island that has its own "characteristics". Madura cannot be separated from Islam, although admitted its populations are illiterate and blind religion that do not know the real of Islamic teachings. Their soul is similar with Bugis, both dare to wade through the great ocean and pitched in between the waves. ${ }^{8}$ Thus, the statement about the consistency of the Madurese in this study is Landak village, especially married without finishing $i d a h$, which in Islam and regulations of the government are prohibited, has been denied by such social change.

To prove the social behavior/reality, the writer uses one of theory of sociology, i.e. social construction of P.L. Berger as a blade analysis in this study and also the Indonesian social jurisprudence approach so that in reviewing social reality does not have drought analysis when it is banged with legal values.

The theory initiated by P.L. Berger is an attempt to reaffirm the essential issue in sociological knowledge. Social construction theory is also responded to sociological knowledge issues such as how is the construction of knowledge can form in the community. Human beings have a free consciousness in giving meaning to their reality, then the consciousness interprets herself and an object based on experienced traits when dealing with the object then flow in their consciousness.

These issues have been studied by other researchers, but conclusions are not the same. The similarities are in using social construction theory in analyzing the cases. The research to date is described below.

Research about $i d a h$. Firstly, this research is to know the working system of USG in detecting an embryo and to describe idah, then how is the law of USG test result as an alternate of $i d a h .{ }^{9}$ Secondly, this thesis explained that a woman married in idah raj'I in Jepara district, and they consider that the marriage is valid. ${ }^{10}$

6 R. Syahrani, The Intricacies of the Principles of Civil Law, Bandung 2011, p. 43.

7 Act no. I of 1974 about marriage; The Compilation of Islamic Law, Bandung 2012, p. 334.

8 RKH F.A. Imron, Syaikhona Kholil Bangkalan: Founding Determinants of Nahdlatul Ulama, Surabaya 2012, p. 27.

9 K. Anam, Islamic Law Review Against Ultrasound Test Results as a Substitute for Idah Period, Yogyakarta 2015, p. 38.

10 Badruddin, The Implementation of Husband's Marriage in the Wife's Iddah Period Due to Raj'i Divorce in Jepara Regency, Semarang 2016, p. 29. 
Thirdly, the discourse of divorce in Islam. There are different views about the right of divorce given to husband. This fact is used to conclude, women have no right to divorce while Islam gives the right of divorce to husband with all its provisions for the benefit, especially in terms of household. ${ }^{11}$

Research about unregistered divorce. Firstly, the dependence of interpretation and explanation of various legal problems and life in the early era is always oriented to the Apostle, but since he passed away, the law is no longer oriented to a central figure. Since the jurists have begun to establish the authority of their self-reliance, they are faced with a very varied legal problem. This phenomenon is evidence of some of the issues that are considered severe enough for later scholars. They are required to make an interpretation of the text, sort it out in detail, and articulate so that the Qur'an always interacting, adapting and socializing in harmony with culture, especially in divorce case. ${ }^{12}$ Secondly, the marriage could be valid by registering the marriage through the application of marriage (marriage legalization) to the religious court as in Article 7 of the Compilation of Islamic Law and remarried by the Religious Affairs Office (KUA) registration procedure. For unregistered marriage, it may renew marriage on the grounds of a divorce settlement. ${ }^{13}$

Research about social construction. Firstly, the dominant problems which are studied, i.e. television advertising constructs social reality, how is the construction of television advertising on social reality in capitalist society. Besides, the writer also studies other phenomena around social construction which is supposed to influence people in making a decision. Then the discussion in this book also corrected the idea of the social construction of the social realities of Berger and Luckman. The writer chooses social construction as the main frame of mind in this book, besides uses as a theoretical concept. But in explaining social construction, as well as clarifying the framework of social construction thinking, the author uses several theoretical concepts, such as the theory of symbolic interaction, semiotics, mass media theories, theory and concepts of capitalism. There are some of the important findings revealed in this book include the social reality of mass media, where the social reality of television commercials constructed by the creator through the mass media, can be divided into three layers. These layers consist of technological reality layers, iconic reality (imaging reality) and verbal or linguistic reality. Then the next finding is the processing of social media construction, where the reality of television advertising is shaped by several groups governing the content of the mass media, i.e. advertising agencies,

${ }_{11}$ A. Mayasari, Divorce and Idah in al-Qur'an (Study of Hermeneutics of Amina Wadud Muhsin), Yogyakarta, 2016, p. vi.

${ }^{12}$ M. Syar'i, Divorce Law Reform Out of Court, "Journal of Islamic Legal Thought Mazahib" 2015, vol. 14(1), p. 18.

${ }^{13}$ E. Widiasmara, The Position of Unregistered Marriage and Divorce in Review of Islamic Law and Legislation in Indonesia, Semarang 2010, p. 9. 
advertising companies and television advertising audiences themselves. ${ }^{14}$ Secondly, the author says, humans in interacting make and use symbols. Long ago, people of Manado, when they heard or saw a pregnant woman, must assume have married legally. So, they have constructed that sexual relationship occurs only in legitimate marriages of religion and state. But now teenagers have sex before marriage and are pregnant before marriage. This has been regarded by society as nothing extraordinary. This is because previously there were the same cases and others (teenagers), follow the symbol that has through the internalization process of the objectified symbols. ${ }^{15}$

\section{RESEARCH METHOD}

This research uses social construction qualitative research approach with case study design/empiric. The data source in this paper are: four married women without $i d a h$, parents/family, public figure and religious leader. Data were collected by observation, interview technique, and documentation. The data analysis technique begins with checking the data validity by using triangulation of source data, presentation of data, analysis with social construction by P.L. Berger and the Indonesian social jurisprudence approach, and conclusion.

\section{SOCIAL CONSTRUCTION OF UNREGISTERED DIVORCED WOMEN WHO MARRIED WITHOUT FINISHING IDAH}

Based on the data obtained, there are several findings. Married women without finishing $i d a h$ assume that $i d a h$ is not to be done because before divorce they have been left to wander by their husbands. For the first woman, it is is a year and three months, the second - more than two years, the third - one year and nine months, and for the last one - less than one year. During abandonment, they are endowed even though they are not sent every month. In addition, they face life difficulties after divorce from their husbands, difficult economic conditions, the reality of social status because it has been regarded as unlucky and unmarried women. The traditional demands that women who reject the proposal of men are not good according to society because it can cause difficulty to get the next proposal. They

${ }^{14}$ B. Bungin, Social Construction of Mass Media: The Power of Influence of Mass Media, Television Advertising and Consumer Decisions and Criticism of Peter L. Berger \& Thomas Luckman, Jakarta 2008, p. 33.

${ }^{15}$ C.R. Ngangi, Social Construction in Social Reality, "Agri-Sosioekonomi” 2011, vol. 7(2), pp. 1-4. 
have a purpose why get married without $i d a h$, i.e. to improve their economic, get social status as women dignity, welfare and give good future for their children.

Other findings of marriage without $i d a h$ includes that they understand that $i d a h$ must be done for divorced women, both in Islamic law and act. However, due to the fact of life after divorce, the divorced woman is finally forced to decide to marry without idah but also forced by parents and social status. Researchers also found a central role in marriage without $i d a h$ in the Landak village, namely the religious leaders who marry the woman.

The helplessness of women in Landak village in living complicated life after being divorced by their husbands is the imbalance in education, both by parents and by existing tradition. The existence of women classification in cultural system Landak village including descendants of religious leaders which generally study in Islamic boarding school. Descendants of the rich which is generally educated at the elementary school until boarding school, and the descendants of ordinary people or weak economists who largely missed primary school.

In fact, there is still no case study similar to this one developed by the author. So that, this is the first research both in the subject, object and focus study. The theory used is the social construction of Berger which consists of externalization, objectivation and internalization as in some references of social construction. In addition, in this research, the author uses the three basic dialectics of Berger's social construction that begin from externalization, objectivation and internalization. So that, the social construction of marriage without idah for unregistered divorced women, became inevitable in the midst of Madurese society, especially in Landak village known as the religious community. The change of religious doctrine in legitimizing "marriage without $i d a h$ for unregistered divorced woman" is analyzed below.

\section{Externalization: moments of outpouring of post-divorce and marriage without idah}

This process is an implementation of internalization process that has been done or would be perpetuated into the world, both in physical and mental activity; in this case, the social activities that have been introduced to it. Basically, since birth, the individual knows and interacts with the social creation. While the creation/social product itself is everything the result of socialization and interaction in society, externalization in social construction theory is a necessity for humans whose nature is being cultured, social and have biological desires. So the social order is something that already exists and precedes every development. ${ }^{16}$

In this case, the process of marriage of women who unregistered divorce in women life texts is unknown, especially in women life, but with the ongoing inter-

\footnotetext{
${ }^{16}$ P.L. Berger, Holy Sky: Religion as Social Reality, Jakarta 1991, pp. 4-5.
} 
action of life, something unusual happens like marriage without $i d a h$, but now it is used as a social reality/phenomenon, either by certain persons for their undisclosed or as openly transparent marriages. In this case, married women without idah adapt and interact with the social world in their environment. The externalization process is illustrated in the following two adaptation processes.

Firstly, adaptation process of the outpouring of selfhood with the texts of their life. In response to social phenomena, the women married without $i d a h$ argue with the basis of their life experience after a divorce, they reassured the public that the action that has been done is a necessity of their life. In this case, the women positioned life texts such as the economic conditions which then gave rise to pragmatic attitudes, information technology that also affected them, the social tradition which was justification for the legitimacy of the figures, that rejecting the proposal was a bad act, they positioned as central position and as an instrument of life view, including in taking action or doing marriage without $i d a h$.

It is as revealed by the perpetrator, that they do marriage without idah, in addition to having been abandoned by their husbands also because of the pressure of tradition about women who do not have family ostracized or if refuses proposal not considered good. The willingness of good life, the technological influence that causes them can connect with the other men after or before the divorce, social traditions such as maintaining the greatness of family until the figure gives them room for marriage which is still in idah.

Secondly, adaptation process with values and actions. In this adaptation, there are two possible things, i.e. acceptance and rejection. In the acceptance process of the values and actions are reflected from their participation and the community receives them, such as when there are people who have an intent, they have a role and provide the needed assistance. In addition, married women without idah are not treated differently, as evidenced by social communication, their social interaction with the community can still intermingle in the local culture.

While those who refuse, this happens in a more religious environment or social status. Because the rejection is done by religious leaders, although there are some people who are still classified as abstract (vague/pseudo). Those who refuse generally base their views on religious texts that do not allow to marry, because they have disregarded the idah that obliged divorced women.

\section{Objectivation: institutionalization moment, legitimacy and habitualization after marriage without idah}

The process of objectivation is also called the interaction between two mutually exclusive realities or between the person and the socio-cultural reality. These two separate entities then form a network of intersubjective interactions (reciprocity). In the process of social construction, this process is referred to as social interaction 
through institutionalization and legitimacy. Institutionalization will occur when there is an intersubjective agreement. In addition, the objectivity of institutional is an objectivation created and built by a man himself. In this case, the process of objectivation occurs, i.a., in the following cases.

Firstly, the marriage of woman without $i d a h$ and social institution are two different entities. The intersubjective dialectic between the married woman without $i d a h$ and the different real-world outside herself is very possible to create a new "meaning" in understanding the marriage and the household to be lived. The married woman without idah, also in accordance with the institution (family, community) and beyond her, is considered as two distinct entities over the subject's demands. It is often not realized that a person's actions, both appropriate and incompatible beyond themself, are human actions that process (to be) through the stages of social construction. However, it is often not realized that the action is a human act which proceeds (to be) through the stages of social construction.

Secondly, institutionalization. It is the process of building awareness into action. In this process, the value that becomes the guideline in making the meaning of the action has become an integral part, as acknowledged by principals, that after doing the marriage, they feel unpredictable for what they find and feel so that what they realize is what they do. They marry without idah is not only based on the traditions, the environment, the legitimacy of the leaders, merely follow-up, but also they understand and realize the overall argumentation of the purpose and the benefits of their actions.

Thirdly, the last stage is the process of habitualization. The married woman without idah no longer needs much meaning for action, because the act has become part of the calculation and introspection. Thus, when the action she do has become habitual, then it has become a spontaneous act. The act is externalized by woman, since then the marriage without $i d a h$ become important and phenomenal, especially for women of Landak village. The marriage without $i d a h$ has meaning as a helper and a way out for divorced woman on the fact of life, tradition and her wishes, so that it can be externally annexed every living space of unregistered divorced women.

\section{Internalization: the absorption moments after marriage without idah}

Internalization is the individual as the subjective reality of interpreting objective reality or the re-enactment of reality by man, and transform it from the structures of the objective world into the subjective world. At this moment, the individual will absorb everything that is objective and will be realized subjectively. A family, understanding and individual action will be formed according to the understanding held. In this context, a family dominated by worldly understandings will produce material, calculative understandings although there will be little religiosity to support it, and vice versa, and so on. 
Firstly, the existence of a calculative pragmatic in every action done by individuals or groups must have a certain goal to be achieved. The goal is to form an independent life, well-being, regain social status as married and sociable women with dignity, and future guarantees for their families. Moreover, achieving their calculative goals through marriage without $i d a h$ is to keep family honour in society.

Secondly, the religious and social aspect. In this moment, the perpetrators, that has the status as religious women, would be unethical if they would have sexual intercourse in the middle of society without the legitimacy of the religion held. Thus, the marriage will keep their religious social status in the community, regardless of the judgement they will get after the action is taken.

Thirdly, the religious and normative aspect. Related to religious norms or religious law Madurese, especially Landak village, is a religious society, moderate because their teaching is the advice of scholars (kiyai) who embraced Nahdlatul Ulama. In practice, Landak society looks thick with local customs. In this case, married women without $i d a h$ believe that their actions do not violate the religious rule, because the omniscient God and the most merciful will forgive them.

The social construction of married women without idah can prove that the people who reflect the devotion of their religion are evidenced by the names of Muslims who have long been used, such as names derived from the Holy names of Allah and the Prophets. However, in line with the basic concepts of social construction theory, humans basically will continue to process in creating social products to other social products.

With the various motives which make the women want to achieve the goals, ultimately their impetus for such action is the most important. They are even optimistic that their action will gain God's gift as proof of His caring and loving. As in the study of social jurisprudence of K.H. Sahal Mahfudh, that contextual welfare depends on aș-șidqu, al- 'adlu, dan ar-rahmah. Messages of the Prophet, i.e. rahmatan li al-'alami $>>n$. While justice in the Qur'an concept is understood as a balance in human life. That is, God's torment as sanction is balanced with an optimistic attitude towards God's forgiveness. Obligation is balanced with right, physical is balanced with mental courage, and ratio is balanced with physical potential. ${ }^{17}$ According to the scholars, the basic law of $i d a h$ for women is $q$; at ' $^{\prime} i$ and there was no reinterpretation. However, the real life of women differs from what Musdah Mulia said that "idah is the transition to rethinking between the two sides how to build a future life". ${ }^{18}$ It is, on the contrary, the divorce that befell the women in Landak breaks up everything, so it is not given nafka, the life of the post-divorce is borne by the husband who divorces the woman, even the woman feels

${ }^{17}$ K.H. Sahal Mahfudh, Nuances of Social Fiqh, Yogyakarta 2003, pp. xiv-xivi.

${ }^{18}$ I. Mustofa, Study Analysis of Siti Musdah Mulia's Thoughts about the Concept of Idah and Its Significance to Changes in Islamic Law, Semarang 2012, p. 243. 
miserable, deprived, and earn livelihood without marriage for the sake of survival of their family.

Related to the case, the imam of school divides into two events related to marriage without idah. Firstly, according to Maliki school and Hanbali school, the man is not allowed to marry the woman forever. Secondly, the man is allowed to marry the woman after idah - this is according to Hanafi school, Syafi'i school and Hanbali school. Syafi'i school and Hanafi school said that the woman in this case is finishing the idah from the first husband. ${ }^{19}$ In the Compilation of Islamic Law Article 40 (b) and Article 71 (c) about marriage can be canceled, as follows:

- the Compilation of Islamic Law Article 40 (b): "woman in idah is not allowed to marry", married is forbidden for her, ${ }^{20}$

- Article 71 about marriage can be annulled point c: "The married woman is still in the idah". ${ }^{21}$

The law must be obeyed by the Muslim community in Indonesia. But the problem still exists, as it is said in the basic social construction concept, that human beings are constantly experiencing the process, change, experiencing the creation of social products and as a result have an impact on changes in the social order, individually, and in the social community.

Whereas in the state laws and in Islamic law, the purpose of marriage are: (1) obtaining and carrying offspring; (2) lust distribution and shedding compassion based on responsibility; (3) maintaining from damage. So, according to the writer, it is needed to get more attention, not only seen from hablum minaalla $>h$ (relationship with Allah) according to Musdah gets more portion, but legal aspects hablum minanna $>s$ (relationship with humans) must also get a balanced portion in order to avoid the tendency of applying the lame law, based on the applicable law source, both the religious law source and the state law source.

There are three conclusions that could be presented, namely: social reality form, the construction of marriage without $i d a h$ process over the social reality, and the meaning and social implications of marriage without idah for community.

Firstly, divorce makes social reality, an unavoidable fact of life. The social reality where the divorce happened is a result of individual and society products. The creation of reality is meant by using the unimproved stages, that reality is real, realistic, even without realistic origins. So through these stages, the individual is in a real space in every view of his life. Even almost no real reality space for individuals such as divorced women.

Secondly, the reality of divorce is shaped by agents involved in the divorce itself, such as family, husband, third party, and society. The husband's role is due

19 I. Qudamah, Al-Mughni, Riyadh 1997, pp. 102, 202.

${ }^{20}$ Act Number 1 in 1974 about marriage; The Compilation of Islamic Law ..., p. 334.

${ }^{21}$ The Compilation of Islamic Law..., p. 10. 
to the stages of social construction. Social realities of divorce formed based on power relations among other agents, so that with the power can make social reality of divorce with certain limits desired by the husband's role. The relation of power among other agents results in the value used social construction, then results in a process of negotiating meaning and social products against the divorce. The steps take place in a simultaneous social construction, namely: externalization, objectivation, and internalization.

Thirdly, when the divorce becomes real, so the action has into social space that may be widespread because divorce, in reality, will be perceived by the individual and then transmit to others. When the divorce happened, the creation of social reality of divorce aimed at specific individuals, not only consumed by the individual, but also extend to the other individual, either by story telling, share difficulties after divorce even until the marriage without idah happened.

\section{SOCIAL CONSTRUCTION OF VIEW OF RELIGIOUS AND PUBLIC FIGURES ABOUT MARRIAGE WITHOUT IDAH}

Actually, the religious leaders and society in Landak village have tried to prevent marriage without $i d a h$ by advising and providing an understanding of idah. However, the marriage still occurs because of the insistence of the woman who has been divorced and because understanding of $i d a h$ is not as understood by religious leaders, but they understand idah since they did not have sexual intercourse. Besides, there are some religious leaders who receive wages from their families or the women.

Another finding is that adherence to religious leaders is reduced, religious leaders are obeyed only if in line with the conditions faced by the perpetrators. So the marriage without $i d a h$ is not allowed by the religious leaders and society, then they married in a furtive way. Hence, marriage is ignored by society so that gradually become accustomed.

The offender opinion who is more concerned the world made change, ie, the first marriage without idah is a taboo, now become accustomed and not questioned, either by Islamic law or the act. Community leaders do not have anything to do, because the marriage is carried out in secret and unregistered. They prioritize the welfare, wholeness, community serenity. prevent greater damage formerly and the human side.

So that, The social construction of religious leaders and society about marriage without idah, become inevitable, especially in Landak village which is very thick with religious doctrine and traditions, especially about marriage without $i d a h$ which is actually ban for the local community. Here are the social construction dialectics presented by the writer: 


\section{Externalization: the outpouring moments of socio-cultural world}

Externalization is Outpouring of socio-cultural world as human products. Some religious leaders or moderate society, their religion teachings written in religious texts and doctrines need interpretations to be practiced. Then the interpretations not singular or rigid, but are adaptive or appropriate to their lives. The real-life text is social daily life of society and religious leaders.in other words, Externalization process as follows.

Firstly, adaptation with sacred texts referenced. Religious and community leaders positioned the texts as central positions and instruments of their lives, including in acting and carrying out their role.

Secondly, adaptation with values and actions (relationships with local communities). It is depicted in the daily religious and community leaders who can mingle without questioning the women who divorced, then married without $i d a h$. Also there is rejection expressed through several statements, such as: forced to let them married without $i d a h$ for self-justified reasons, to give an envelope to realize their marriage.

\section{Objectivation: interaction moments with socio-cultural world}

This moment is the result of externalization which has manifested itself as a single objective reality. In the process of social construction, it is called social interaction through institutionalization and legitimacy. Conceptually, the process of objectivation can be explained as follows.

Firstly, in this context, intersubjective dialectics between religious leaders and society with the real world, the differences beyond them allows a new meaning in understanding marriage without $i d a h$, both religious leaders and society. However, it is often not realized that a person's actions, both appropriate and incompatible beyond themself, are human actions that process (to be) through the stages of social construction. However, it is often not realized that is a human action which proceeds (to be) through the stages of social construction. That as a reality, they will always try to achieve the dialectical process between religious leaders and society.

Secondly, institutionalization is the process of awareness building into action. In this step, either religious leaders or society do not only based on what had been done by their progenitor, but also they understand the arguments, both of the purpose and the benefit of their action.

Thirdly, habitualization process is the processing when rational action which has purpose had been daily activities. This step does not need more interpretation of the action because it had been a part of its cognitive and evaluative system. So allowing a marriage without $i d a h$ becomes real for some religious leaders, but it becomes unreal for others. 


\section{Internalization: the absorption moment of socio-cultural world}

There are two important things in the self-identification. Firstly, primary socialization in which the family becomes the most important social institution for individual, hence this family would be formed understanding and action based on interpretation adopted. It means a family dominated by a deep religious understanding, so will create deep religious thought transformation. Secondly, secondary socialization is the existence of an organization. In this context should be mentioned the traditionalist Nahdlatul Ulama ${ }^{22}$ organization. The organization becomes an effective way in shaping the religious leaders and society mindset.

In essence, in many social construction studies, social construction occurs due to two factors, i.e. internal and external factors. According to the Weberian school is called "in order to motive", in the Schulz school is called "because of motive". And according to Berger is called "pragmatic motive". ${ }^{23}$ Purposed motives based on the action could be expressed such as: (1) ideal motive is the awareness of preventing of larger damage in the life of poor women after the divorce which makes their ability to help the welfare of women who divorced with realizing marriage without $i d a h$. Without motivation, it will not make a peaceful society; (2) practical motive is the marriage without idah caused an action to build family welfare; (3) interest motive is an important and urgent motive that person did. In this case, there are two motives, i.e. ideal dan practical motives. An ideal motive in this context is marriage without $i d a h$ that becomes humanism and social aspects besides ethical morals. It means, either religious leaders or society who accept a marriage without idah argue that it can build family welfare, attach importance to humanitarian and ethical values in association between unmarried women and unmarried men. While the practical motive is encouragement to meet the interests of the individual or married woman without idah. Everyone has action, then the first thought is whose interests will be met and how much importance it has a positive impact on the individual. In this case, both the religious leaders and society regard whether marriage without $i d a h$ is useful for them or not, so their understanding and interpretation related to this case is always based on interest consideration.

\section{DISCUSSION AND CONCLUSIONS}

The article analyzes the issue of the social construction of women who married without finishing idah. The point of view of three motives was taken. Firstly, an

${ }^{22}$ Nahdlatul Ulama is the largest Islamic organization of ahlu sunnah wal jamaah in Indonesia.

${ }_{23}$ See M. Zainuddin, Religious Pluralism in the Analysis of Social Construction, Malang 2014, p. 80 . 
ideal motive - the awareness of marriage without finishing idah is being the cause of their interest and faith. So they believe that the action can change reality of their life which is difficult to pursue alone. Secondly, a practical motive - a marriage without $i d a h$ causes a sense of solidity in the family, keeps the family reputation, re-creating harmony among women, and helps each other to create harmony. Thirdly, an interest motive - it is a combination of ideal motive and practical motive. The ideal motive in "marriage without idah" is the "kinship conscience" and "social status" aspect while the practical motive is the insistence to meet the individual interest.

The construction of religious figures and society is also very important. Firstly, awareness about preventing damage is greater for women who live in poverty after divorce, this is what makes them care in helping women's prosperity after divorce, thus allowing marriage without idah. Secondly, marriage without idah is a practical motive to make a prosperous family and homely. Thirdly, there is an interest motive. Besides ethical morals as their ideal motive there are humanism and social community aspects while the practical motive is an impulse to meet individual interest for women who married without idah.

\section{REFERENCES}

\section{Literature}

Abi ‘Abdillah Bin Muhammad Bin Yazid Ibn Majah, Sunan Ibn Majah, Riyadh 1998.

Anam K., Islamic Law Review Against Ultrasound Test Results as a Substitute for Idah Period, Yogyakarta 2015.

Badruddin, The Implementation of Husband's Marriage in the Wife's Iddah Period Due to Raj'i Divorce in Jepara Regency, Semarang 2016.

Berger P.L., Holy Sky: Religion as Social Reality, Jakarta 1991.

Bungin B., Social Construction of Mass Media: The Power of Influence of Mass Media, Television Advertising and Consumer Decisions and Criticism of Peter L. Berger \& Thomas Luckmann, Jakarta 2008.

H.S., Interview, Landak, 13 August 2016.

Imron F.A. RKH, Syaikhona Kholil Bangkalan: Founding Determinants of Nahdlatul Ulama, Surabaya 2012.

Mayasari A., Divorce and Idah in al-Qur'an (Study of Hermeneutics of Amina Wadud Muhsin), Yogyakarta 2016.

Mustofa I., Study Analysis of Siti Musdah Mulia's Thoughts about the Concept of Idah and Its Significance to Changes in Islamic Law, Semarang 2012.

Ngangi C.R., Social Construction in Social Reality, “Agri-Sosioekonomi” 2011, vol. 7(2).

Qudamah I., Al-Mughni, Riyadh 1997.

Sabiq S., Fiqh as Sunnah, Beirut 1988.

Sahal Mahfudh K.H, Nuances of Social Fiqh, Yogyakarta 2003.

Syahrani R., The Intricacies of the Principles of Civil Law, Bandung 2011.

Syar'i M., Divorce Law Reform Out of Court, "Journal of Islamic Legal Thought Mazahib" 2015, vol. 14(1). 
Pobrane z czasopisma Studia Iuridica Lublinensia http://studiaiuridica.umes.pl Data: 26/04/2023 15:30:08

The Compilation of Islamic Law, Bandung 2012.

Widiasmara E., The Position of Unregistered Marriage and Divorce in Review of Islamic Law and Legislation in Indonesia, Semarang 2010.

Yusuf M., UIN Ar-Raniry Banda Aceh, Build Fiqh Contemporer Concept, "Journal of Syarah" 2020, vol. $9(2)$.

Zainuddin M., Religious Pluralism in the Analysis of Social Construction, Malang 2014.

\title{
Online sources
}

Kamus Besar Bahasa Indonesia, Idah, https://kbbi.web.id/idah-2 [access: 10.11.2021].

\begin{abstract}
ABSTRAKT
Małżeństwo bez zachowania okresu iddah jest uznane za czynność prawną i dozwolone dla kobiet po niezarejestrowanym rozwodzie. Czynność taka została dokonana przez H.S., rozwiedzioną z mężem T.B., który porzucił ją na rok i trzy miesiące, wyjeżdżając do Malezji. Madurowie, a szczególnie wioska Landak, stanowią społeczności religijne. Jednakże rzeczywistość społeczna przeczy uznawaniu ludności z regionu Landak za społeczność religijną. W niniejszym artykule podjęto dwa problemy badawcze: 1) Jaka jest społeczna interpretacja statusu kobiet, które zawarły małżeństwo bez zachowania okresu iddah? 2) Jakie są opinie wśród autorytetów religijnych i społeczeństwa w miejscowości Landak w powiecie Bangkalan w regionie Madura w Indonezji na temat małżeństwa bez zachowania okresu iddah? W efekcie przeprowadzonych analiz stwierdzono, że: 1) społeczna interpretacja statusu kobiet zawierających małżeństwo bez zachowania okresu iddah wskazuje na motywację idealistyczną oraz na to, że istnieje motyw praktyczny i motyw interesu; 2) interpretacja autorytetów religijnych i społeczeństwa jest taka, że pierwszym motywem - idealistycznym - jest zapobieganie większej szkodzie, drugim motywem - praktycznym - jest dobro rodziny, trzeci zaś to motyw interesu, który zawiera aspekt „humanizmu” i „społeczeństwa”, a realizacja danego interesu jest traktowana jako motyw praktyczny.
\end{abstract}

Słowa kluczowe: małżeństwo; iddah; rozwód; społeczna interpretacja 